\title{
Das virtualidades do cuidado da infância em Rousseau ao seu pleno governo na arte pedagógica
}

Pedro Angelo Pagni

Professor Adjunto da UNESP, campus de Marília

\section{Resumo}

Este artigo analisa a gênese e o desenvolvimento da relação entre a arte pedagógica e a infância. Ao abordar esse tema, procuramos salientar as virtualidades do cuidado com a infância postulada por Rousseau e, também, por Kant, em sua gênese moderna, em contraposição a um governo extremo ou ao domínio que se exerce sobre ela ou a partir dela, em seu desenvolvimento subsequente na contemporaneidade. Discutimos, dessa forma, o quanto essas virtualidades foram abandonadas pelas práticas compreendidas pela arte pedagógica, em vistas a encontrar um lugar para o pensamento de Rousseau e de pensá-lo na sua atualidade.

Palavras-chave: cuidado de si; governamentalidade; Jean-Jacques Rousseau

\begin{abstract}
This article discusses the genesis and development of the relationship between art education and childhood. To address this issue, we highlight the virtualities of the care with childhood postulated by Rousseau and Kant, also in its genesis, as opposed to an extreme government or to the domain that has on it or from it, in its subsequent development in contemporary times. Discussed, in this way, how these virtues have been abandoned by the practices included by art pedagogical, in order to find a place for thought of Rousseau and think it in its actuality.
\end{abstract}

Keywords: care of themselves; government; Jean-Jacques Rousseau

Filosofia e Educação - ISSN 1984-9605 - Volume 4, Número 2

Outubro de 2012 - Março de 2013 


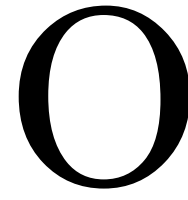

presente artigo analisa a gênese e o desenvolvimento da relação entre a arte pedagógica e a infância. Ao abordar esse tema, procuro salientar as virtualidades do cuidado com a infância postulada por Rousseau e, também, por Kant, em sua gênese moderna, em contraposição a um governo extremo ou ao domínio que se exerce sobre ela ou a partir dela, em seu desenvolvimento subsequente na contemporaneidade. Discuto, dessa forma, o quanto essas virtualidades foram abandonadas pelas práticas compreendidas pela arte pedagógica, embora se mantenha no cerne do discurso pedagógico, na atualidade, porém, certa impossibilidade de retomá-las em razão das atuais circunstâncias históricas.

Este é o principal paradoxo que objetivo evidenciar neste artigo. Para tal propósito, apresento o seu desenvolvimento moderno em duas tendências distintas, porém, intercomunicáveis entre si, que preponderaram no campo pedagógico. Em ambas faço notar que a infância enquanto estado natural e idade específica foi colocada ora como sujeito, ora como objeto de governo por essas tendências da arte pedagógica, que encontram na Filosofia da Educação respaldo para o seu exercício e se justificam pelas (meta) narrativas da formação. Defendo que para além desse exercício de governo ou de governança da infância exercida pela arte pedagógica é possível se interpor uma forma de cuidado ético de si que, na relação com outrem, pode significar um cuidado da própria infância do educador. Assim, encontro na gênese moderna desse exercício da arte pedagógica as suas virtualidades para, então, mostrar a supressão dessas últimas pelo exercício pleno de um governo ou de uma governança da infância ocorrida em seu desenvolvimento subsequente. E, ao criticar esse estado de dominação, argumento pela necessidade de uma interposição do cuidado de si do outro

Filosofia e Educação - ISSN 1984-9605 - Volume 4, Número 2

Outubro de 2012 - Março de 2013 
por parte do educador que lhe remeta a uma infância do pensar e a uma atitude ética que lhe permita certa relação de autoridade com os seus alunos.

Embora aborde o pensamento de Jean-Jacques Rousseau como parte desse percurso, gostaria de acrescer este artigo a homenagem, prestada por este dossiê, pelos seus 300 anos de nascimento e pelos 250 anos de publicação de sua notável obra Emílio ou Da educação. Estrategicamente, porém, ele se propõe a encontrar o seu lugar nessa genealogia das relações entre a arte de governo e a infância e apontar para uma leitura dessa obra que, embora não se proponha a retomá-la, a utiliza para situar um problema do presente, instigando os educadores a pensa-lo. Estes são os principais propósitos a que se circunscreve este artigo.

\section{Das virtualidades da infância à arte de governo pedagógica}

No século XVIII, começa a se delinear uma relação da infância com a arte pedagógica, em termos filosóficos, em que a consciência da particularidade infantil e o autêntico sentimento dos adultos em relação à criança passam a ser ainda mais valorizados. A infância passa a ser almejada pelos pedagogos, filósofos e moralistas, não mais como objeto pleno de governo, mas a ser explorada em suas virtualidades naturais e potencialidades humanas, desenvolvidas em vistas à constituição de uma consciência autêntica, como um governo de si mesmo conforme a vontade natural e em contraposição ao governo de outro, já corrompido pela sociedade.

Jean-Jacques Rousseau foi um dos primeiros a conceber essas virtualidades naturais da infância e as potencialidades humanas que continha, apresentando a educação, por assim dizer, como uma arte que cuidaria desse outro até que pudesse se cuidar por si próprio, preservando aquilo que traz de natural, a sua vontade e liberdade originária. Afinal, este seria o móvel para a formação da consciência moral e para a inauguração de

Filosofia e Educação - ISSN 1984-9605 - Volume 4, Número 2

Outubro de 2012 - Março de 2013 
um mundo novo, que funcionaria de acordo com a harmonia natural. Se agisse segundo essa natureza original e uma consciência moral formada autonomamente, de acordo com Rousseau (1995), o homem não se dobraria as convenções sociais estabelecidas e as palavras sedutoras, responsáveis pela sua corrupção. A pureza originária da infância seria, desse modo, preservada e cuidada por meio da educação, pois consistiria em um momento em que as disposições do caráter se formariam em conformidade com essa mesma natureza, nutrida pelo amor de si e ao próximo que nascem com o homem e que o guiam em seus primeiros anos de vida ${ }^{1}$. E, caso se levasse esse mesmo funcionamento natural para a ordem social, assim, teríamos um mundo novo, harmonioso e perfeito tal qual a natureza, ao qual o homem, esse novo homem formado pela nova educação, poderia habitar.

Foi esse naturalismo que, subsequentemente, serviu de inspiração às teorias pedagógicas de Pestallozzi, de Basedow, entre outros. Na apropriação que fazem de Rousseau se nota já um endurecimento em relação ao cuidado da infância para que a ação formativa que pressupõe pudesse ser traduzida na forma de um conjunto de práticas, de procedimentos ou, em uma palavra, em uma arte chamada pedagógica, que pudesse ser implementada nas escolas e servisse ao governo da infância. Tais práticas procuram romper com uma tradição de filósofos, moralistas e

\footnotetext{
${ }^{1}$ Já que esses sentimentos não podem ser traduzidos completamente em uma linguagem articulada, a infância se constitui na origem do próprio pensamento, a condição de sua emergência em um momento em que ainda não se traduz em palavras e em discurso lógico. O critério de verdade desse pensamento diz respeito a uma sensibilidade racional a partir da qual avalia a veracidade das coisas e a justeza de seus atos. Tal pensamento pode continuar indizível, sem que isso implique em um erro lógico, mas apenas em um reconhecimento de seus próprios limites para designar essas coisas e atos, com os quais o ser humano se relaciona em seu íntimo. Se a infância parece ser o momento em que o pensamento começa a se desenvolver, desse modo, a pedagogia rousseauniana propõe-se em consistir em um meio de seu nascimento, que propicia ao homem julgar as suas convicções e deliberar conscientemente sobre suas ações, graças à consulta ao qual o remete: a uma consulta íntima, pessoal, ao seu coração para saber se as assente ou não, ouvindo a voz de sua própria natureza.
}

Filosofia e Educação - ISSN 1984-9605 - Volume 4, Número 2

Outubro de 2012 - Março de 2013 
de educadores que conceberam que a arte pedagógica deveria exercer o governo a partir das formas de um poder pastoral ${ }^{2}$.

Ao contrário do poder pastoral, a arte pedagógica materializada em um conjunto de práticas a partir dos saberes inspirados na filosofia de Rousseau almejou restaurar a vida neste mundo, devolvendo técnicas de experimentação, de reflexão e de julgamento moral que compreenderiam o governo de si. Ainda que fosse com a proteção concedida e com o cuidado expresso por outrem, o pensamento rousseauniano pressupôs um preceptor que, gradativamente, seguindo o desenvolvimento natural de seu aluno, oferece-lhe as condições para que dele se emancipasse e se tornasse moralmente autônomo. Essa forma de poder não é individualizada, mas personalizada, garantindo que a criança aprenda por e com a sua própria experiência, graças à intervenção do preceptor que age no sentido de chamála a refletir quando não percebe por si que está agindo contra a sua própria natureza, até o momento em que seja capaz de agir conscientemente. Ademais, essa forma de poder presente na arte de governo pedagógica a partir do século XVIII procura articular-se a uma governamentalidade que pretende mediante essa formação pessoal promover uma racionalidade estatal que funcione em consonância e em harmonia com a ordem natural.

No processo de materialização desses saberes e dessas práticas, o que se verificou, porém, não foi propriamente uma ruptura. Ao contrário, se observou uma inversão dessa configuração do poder. Nela a natureza passa a determinar a expressão da vida (nua) e a infância passa a representar, ao invés de um objeto de governo dos adultos e do mundo, um sujeito a

\footnotetext{
${ }^{2}$ Para usar essa designação de Foucault (2008), o poder pastoral se exerce de maneira individualizada, e não centralizada pelo Estado, em cada um dos integrantes do rebanho, tendo o pastor a responsabilidade de agrupar este último para conduzi-lo e salvá-lo de sua dispersão. A tecnologia por ele adotada exigiria do pastor a abnegação para assumir essa responsabilidade de guiar o destino do rebanho e se destinaria, por meio das técnicas de exame, confissão, direção de consciência e obediência, que cada um de seus integrantes levasse a cabo a sua própria "mortificação" neste mundo para alcançar a vida eterna em outro (2008, p. 116).
}

Filosofia e Educação - ISSN 1984-9605 - Volume 4, Número 2

Outubro de 2012 - Março de 2013 
governá-los, na expectativa de que possam ser adultos melhores no futuro e, consequentemente, existirem em um mundo melhor. O que se verifica nessa forma de governo é uma abnegação por parte do educador de se responsabilizar pelo cuidado com a infância, colocando sobre os ombros desta tal responsabilidade em conduzir o mundo, senão no presente, ao menos no futuro. Implica, dessa forma, em outra forma de mortificação que compreende o sacrifício da própria atuação e da anulação da autoridade dos mais velhos no presente para garantir que os mais jovens possam ser pessoas e criar um mundo melhores, no futuro. Como se os adultos não precisassem viver, tampouco atuar politicamente, mas somente esperar uma transformação que adviria das crianças.

O problema seria o de que, sem a tradição, a autoridade e a ação formativa dos mais velhos, a liberdade esperada não emergiria por si só, naturalmente. Ao invés disso, sem supor a elevação do estado de selvageria à crítica do julgar, essa forma de cultivo da infância pela arte pedagógica ocorreria com a sua exposição à natureza e à vida nua, resultando em um laissez faire que omite a destruição da vida pública e uma tirania que se exerce pelos mais fortes. Contraditoriamente, assim, em nome da crítica à tradição e da liberdade em relação à autoridade se constitui, na arte de governo pedagógica, um novo estado de dominação que é a cópia invertida de seu antecessor, onde quem governa o outro não são os mais velhos, mas o mundo infantil.

Esse problema político - o da liberdade - que ecoa na arte de governo pedagógica, nos termos ora indicados, parece ser o objeto central de discussão do ensaio jornalístico de Immanuel Kant sobre a Aufklärung. Após ter definido a Aufklärung como a saída do homem de seu estado de menoridade do qual ele próprio é culpado, por falta de aptidão e coragem, Kant (1974) enuncia um problema em relação à liberdade, quando esta é pensada apenas do ponto de vista do indivíduo. Ele perspectiva formulá-la

Filosofia e Educação - ISSN 1984-9605 - Volume 4, Número 2

Outubro de 2012 - Março de 2013 
do ponto de vista transcendental, argumentando que desse ponto de vista se garantiria uma posição livre do interesse particular, favorável a constituição de um uso da razão pública universal e o lugar de realização mesma da dignidade humana. Para Kant (1974), a liberdade formulada do ponto de vista individual, ao ignorar a necessidade do uso privado da razão nas esferas públicas e se pautar apenas no uso público da crítica, propõe a romper imediatamente com os costumes, as crenças e a tradições, resultando em uma destruição da ordem civil e na interrupção do movimento da Aufklärung. Tampouco procura defender dogmaticamente os costumes, crenças e tradições, restaurando uma autoridade pastoral. $\mathrm{O}$ filósofo alemão entende que para que ocorra esse movimento de um ponto de vista transcendental é necessário que a crítica opere publicamente para que, gradativamente, após muita ponderação e raciocínio, se emancipe daquelas, sem colocar em xeque a ordem civil, que favorece o desenvolvimento da Aufklärung. Por isso, o seu uso restrito na esfera pública, quando se atua em instituições responsáveis pela transmissão da tradição, ou seja, a obediência, não é contraditória com o uso público da razão e do entendimento, o raciocinai o quanto quiserdes e sobre o que quiserdes. Parece ser neste sentido filosófico e político que se apoia a pedagogia kantiana.

Se a pedagogia rousseaniana rompe com o poder pastoral, oferecendo outros contornos à infância na arte de governo pedagógica, na acepção de Foucault (2000), o ‘não querer ser governado desse modo’ ou o que a modernidade caracterizou como crítica estaria mais próximo da Aufklärung, nos termos em que Kant o analisou em seu ensaio jornalístico sobre o assunto. Isso porque, do ponto de vista do projeto crítico kantiano, o apelo à coragem (própria da natureza) é modulado pela obediência, pelo respeito à autoridade instituída e à proposição de outra arte de governo, superior, porque regida por um ideal verdadeiro e por uma moral transcendental. Para Foucault, a resposta dada por Kant ao problema da 
Aufklärung é 'sapere aude', não sem que outra voz, a de Frederico II, diga em contraponto "que eles façam uso da razão tanto quanto queiram, conquanto que obedeçam”. Assim, a crítica seria o que Kant postula em relação ao reconhecimento dos limites do conhecimento e do pensamento no sentido de instigar que se diga até que ponto vai o saber e o pensar, respectivamente, com segurança e sem perigo. Em outras palavras, a crítica seria concebida como reconhecimento dos limites do conhecimento e como o processo pelo qual o pensamento chegaria a uma ideia de autonomia que estaria longe de se opor à obediência aos soberanos.

Pode-se dizer também que, em termos kantianos, historicamente, a sua crítica teria se contraposto ao processo geral de governamentalização e, ao mesmo tempo, participado de sua distribuição por outras artes específicas (jurídicas, religiosas, pedagógicas) de um modo bastante singular. Kant parece sugerir uma alternativa às formas precedentes de governamentalização, insistindo 'em um não ser governado do modo', marcado pela obediência irrestrita ao soberano, seguindo as lições de $O$ Príncipe (FOUCAULT, 1990, p. 179-180), e pela aquisição de uma ascese ou de uma disciplina monástica (FOUCAULT, 1991, p. 127). Tal alternativa pode ser demonstrada em algumas obras de Kant, publicadas proximamente ao seu ensaio sobre a Aufklärung, no contexto em que o príncipe seria apenas uma das modalidades de governo, juntamente com o pai de família, o superior no convento, o pedagogo ou o professor na escola.

No que se refere à modalidade de governo pedagógica, o filósofo alemão parece apresentar também uma alternativa tanto ao olhar lançado por Rousseau à infância, como pura potencialidade, quanto ao lançado por Descartes, como o lugar do erro lógico, oferecendo outras indicações filosóficas à arte pedagógica (GAGNEBIN, 1987; PAGNI, 2006). Se, por um lado, concorda com Rousseau (1995) no que se refere às inclinações a liberdade da natureza humana e à concepção de que, embora nasça inclinado

Filosofia e Educação - ISSN 1984-9605 - Volume 4, Número 2

Outubro de 2012 - Março de 2013 
a fazer o bem, o homem só se torna moral quando se conscientiza do dever e da lei, por outro, Kant (1995) considera que as inclinações e a consciência não nascem prontas: necessitam serem formadas racionalmente $\mathrm{e}$ direcionadas à constituição de uma moralidade autônoma.

Embora nasçam com as inclinações e as potencialidades para a formação da consciência, segundo ele, as crianças e jovens deveriam, num primeiro momento do processo educativo, ser subjugados por tutores e obedecerem enquanto não são capazes de julgar moralmente; somente, num segundo momento, eles exerceriam a sua liberdade moral, segundo as leis racionais e a razão prática. Diferentemente do cultivo das faculdades inferiores em si mesmas propostas por Rousseau, Kant afirma que elas deveriam ser cultivadas tendo em vista o desenvolvimento das faculdades superiores, tomando-o como a finalidade da razão e compreendendo-a como a sua forma mais alta: a razão prática responsável por legislar sobre a moralidade. Para a pedagogia kantiana, assim, o que deve ser objeto de correção na infância não é ela em si mesma, mas a experiência que a caracteriza e, com ela, a sensibilidade, a memória e a imaginação constitutivas das faculdades inferiores que desviariam a ação humana conforme a razão legisladora e o princípio da moralidade.

Kant reconhece que essa experiência e as faculdades inferiores deveriam ser subjugadas ao entendimento e à razão, gradativamente, acompanhando toda a existência humana. A proposta de abandono da experiência da infância, do uso das faculdades inferiores para o julgamento moral, de saída do estado de inaptidão e de incapacidade racional, por meio de uma pedagogia da razão e de uma educação da moralidade, é complementar ao da saída da menoridade, nos termos definidos por Kant em seu famoso ensaio Resposta à pergunta: o que é o Iluminismo (Aufklärung)? Assim, o olhar filosófico sobre a infância parece se ampliar não se restringindo a uma idade específica, mas a um estado de incapacidade, de 
ingenuidade e de ignorância daqueles que necessitam de cuidados, de tratamento, de leis e de governo, porque possuem uma vida sem razão, consciência e moralidade, devendo dele ser emancipado para alcançar a verdadeira liberdade.

Nesses termos, a arte pedagógica visaria não apenas tornar obediente os cidadãos, como também promover uma forma de governo de si, oferecendo-lhe uma ideia de sujeito, um regime de verdade e de princípios morais a guiá-la, conforme as regras da razão e do entendimento. O governo de si seria harmonizado racionalmente, por meio dessa arte, ao governo do soberano, tendo em vista uma realização necessária e prospectiva da Aufklärung, que se propõe a guiar a saída da menoridade, entendida não como um movimento espontâneo, resultante das disposições da natureza humana e de seu livre jogo, mas como um movimento capitaneado pela crítica da razão. Kant defende, assim, outro sentido à pedagogia e à política, diferente daquele proposto por Rousseau - que tanto o haviam encantado -, com a finalidade de articular o governo de si no sentido de não ser governado de certo modo para, então, produzir outra forma de governamentalização, impulsionando seu processo geral, caso o interpretemos dessa perspectiva foucaultiana.

Com Kant, a noção de infância parece se ampliar não se restringindo a uma idade específica, mas a um estado de incapacidade, de ingenuidade e de ignorância daqueles que necessitam de cuidados, de tratamento, de leis e de governo, porque possuem uma vida sem razão, consciência e moralidade, devendo dele ser emancipado para alcançar a verdadeira liberdade. Assim, Kant parece perpetuar uma tradição em que a infância foi abordada como uma experiência singular, desprestigiada pelas teorias pedagógicas, mas a ser corrigida na arte de governo pedagógica, sendo subjugada a uma racionalidade subjetiva, por intermédio da disciplina e da autoridade empreendidas pelo educador. Mesmo assim, ela também foi considerada 
como uma virtualidade e uma potencialidade humana da qual a constituição do pensamento racional e a formação do sujeito moral necessitam para que o homem, conscientemente, cultive a si mesmo e se torne humano.

\section{Entre a governança e o governo da infância}

Não se pode dizer o mesmo do que foi concebido por Kant como menoridade que, graças ao seu sentido mais amplo e de maior negatividade, com o desenvolvimento subsequente da modernidade, passa a ter um significado pejorativo. A menoridade jurídica ou social, em meados do século XX, passa a ser um dos objetos emergentes das recém-criadas Ciências Sociais. Embora signo da ingenuidade e da ignorância, a população considerada menor pelos tutores se subleva, senão por palavras e por meio de uma linguagem articulada, ao menos por gestos, contra uma ordem civil. A desordem desse pensamento e os gestos de rebeldia manifestos por essa população se tornam objetos das políticas do Estado, legitimados pela ciência do social, buscando um regulamento superior para a vida social, racional, científico, indubitável. Essa desordem da população, posteriormente, será tomada como similar a rebeldia infantil por parte das Ciências Sociais. Isso porque, em sua origem, as Ciências Sociais diagnosticam a sublevação dos considerados menores, a sua desordem de pensamento e desregramento moral, como sintomas de uma crise da moralidade, sem precedentes históricos, a ser objeto de estudos e, se possível, de tratamento.

Confundida com a menoridade, a infância pode ser imaginada como ameaça ao instituído. Como assunto de artes de governo específicas, legislada pelo Estado e regulamentada pelas ciências, neste caso, as virtualidades da infância e as potencialidades humanas tornam-se objetos de uma dura crítica, conjuntamente com a filosofia que a fundamenta, e de uma

Filosofia e Educação - ISSN 1984-9605 - Volume 4, Número 2

Outubro de 2012 - Março de 2013 
governabilidade maior exigida por parte da arte de governo pedagógica. É a partir desse momento que o não querer ser governado de determinado modo e a resistência proveniente da infância passa a ser temida, aspirando ao seu completo assujeitamento no processo de governamentalização produzido pela arte pedagógica e propondo o abandono de sua experiência potencial e as virtualidades, necessárias ao nascimento do pensamento e à enunciação da linguagem. O que se nota nesse momento não é apenas a subordinação da experiência da infância às regras da razão, como também a proposta de que, em seu cultivo, ela mesma fosse regulamentada pela ciência da educação e submetida à voz e à autoridade do educador, na arte pedagógica, sendo assim silenciada.

Esse momento coincide com a emergência das proposições de Émile Durkheim sobre o assunto, que poderíamos chamar de momento durkheimiano. Isso, caso consideremos que a absorção de sua reflexão pedagógica e, particularmente, dos saberes que a apóiam pelas práticas educativas analogamente àquilo que Foucault (2004) denomina de momento cartesiano para a hermenêutica do sujeito, isto é, o momento decisivo da sobreposição da consciência de si ao cuidado de si, como um requisito epistemológico para legitimar a ação do homem em um discurso de verdade e fundá-lo sobre um ideal de sujeito, considerados como superiores a um conjunto de práticas que se caracterizam modos éticos de ser e de se conduzir no mundo.

Esse momento se configura na medida em que, ao converter a infância em objeto de estudos da ciência da educação, Durkheim (1967) tenta desvendar os mistérios da arte pedagógica, solicitando auxílio para que a psicologia e a sociologia ${ }^{3}$ fornecessem, respectivamente, os

\footnotetext{
${ }^{3}$ Em suma, a sociologia serviria para prescreve que essa arte deveria conduzir o homem ao abandono do ser egoísta em que se funda a infância para se converter-se em ser social e se socializar em conformidade com as representações sociais da sociedade moderna, conforme o diagnóstico produzido pela sociologia, a quem cabe definir os fins da educação. À

Filosofia e Educação - ISSN 1984-9605 - Volume 4, Número 2

Outubro de 2012 - Março de 2013
} 
conhecimentos sobre desenvolvimento psicológico da criança e as leis do funcionamento social para a sua qualificação para ser útil à sociedade.

Dessa perspectiva, o sociólogo francês pressupõe uma visão de criança imaginária insólita e surpreendente. Ela seria pura negatividade, não tendo sexo, nome, idade, proveniência social e, principalmente, voz, estando submetida ao jugo dos adultos. Talvez, por isso, represente para eles uma ameaça, um perigo, em função de suas disposições primitivas e humores incontroláveis e de tudo que é provir da natureza, e não do encontro com os adultos, interpelando-os e questionando-os a partir desse lugar que foi esquecido, abandonado e racionalizado. Mesmo assim, para os adultos, essa criança teria um conjunto de disposições naturais, valiosas ao educador, como o tradicionalismo, a credulidade, a receptividade às ordens. "Um espelho", diz Fernandes, "no qual Durkheim projeta um ser fraturado em duas faces díspares, opostas, divergentes: curiosidade, imaginação, instabilidade, de um lado; tradicionalismo, credulidade, receptividade às ordens, do outro" (1997, p. 66).

Respaldado nessa imagem, Durkheim (1967) propõe aos educadores que ajam como magnetizadores, por meio de técnicas que procuram sugestionar os menores para, então, exercer sobre eles o seu poder e a sua autoridade. Para garantir esse exercício de poder e da autoridade sobre os menores, assim como a sua sugestionabilidade, os educadores deveriam pressupor duas condições, similares àquelas necessárias à sugestão hipnótica: (1) a de que a "criança fique, por condição natural, em estado de passividade", já que a sua "consciência contém apenas pequeno número de representações", incapazes de lutar contra as que lhe são sugeridas, e sua vontade é apenas rudimentar, sendo facilmente sugestionável e propensa a

psicologia caberia fornecer os meios para que tais representações fossem interiorizadas pelo ser egoísta que é a criança, graças ao conhecimento de seu comportamento, de seu desenvolvimento e das formas de seu aprendizado, mediante o qual os seus caracteres inatos podem ser moldados, formando a sua personalidade.

Filosofia e Educação - ISSN 1984-9605 - Volume 4, Número 2

Outubro de 2012 - Março de 2013 
agir por imitação; (2) a de que a ascendência que o mestre possui sobre o seu discípulo, "em razão da superioridade sua experiência e cultura", propicia o "poder necessário à eficiência de sua atividade", devendo ser prudente no exercício desse poder para que, analogamente a sugestão hipnótica, a ação educativa tenha garantida a sua eficácia (DURKHEIM, 1967, p. 53).

Para se livrar da infância atemorizante o educador procura agir como um magnetizador, recorrendo algo próximo à técnica hipnótica (proveniente da psiquiatria) para obter autoridade na arte pedagógica. Se, analogamente, o magnetizador tem o êxito de sua influência sobre o hipnotizado determinado pela autoridade advinda das circunstâncias, para Durkheim (1967), o êxito da arte pedagógica se sustentaria por um trabalho de autoridade exercido pelos pais e mestres, libertos do medo originário daqueles ao qual essa atividade se destina: as crianças. Assim, para alcançar o objetivo de "sobrepor ao ser que somos ao nascer, individual e associal um ser inteiramente novo" (1967, p. 54), a educação teria seu êxito condicionado ao esforço mais ou menos penoso para nos elevarmos acima de nós mesmos, ultrapassando nossa natureza individual e livrando-se de nossa infância para nos tornarmos efetivamente adultos normais.

Para que o exercício dessa arte de governo pedagógica ocorresse não seria necessário instigar o temor aos castigos pelas crianças, porque eles nada valeriam se não fossem reconhecidos por elas como justos. Seria necessário para tanto que a própria autoridade do punir fosse reconhecida como legítima por parte de quem é punido. Bastaria que a autoridade necessária ao educador proviesse não de fora, mas de si mesmo, do próprio mestre que acredita, senão em si ou na superioridade de sua inteligência, ao menos na grandeza de sua missão. Uma missão que decorre de uma causa impessoal, feita do respeito às funções desempenhadas socialmente pelo mestre e, por via de sua linguagem, gesto e conduta, passar de sua 
consciência para a consciência da criança. Afinal, conclui o sociólogo francês: a liberdade é filha da autoridade", pois, ser livre não é fazer o que se quer, mas ser "senhor de si, saber dirigir pela razão praticando o dever", cabendo a criança habituar a reconhecer na autoridade e na palavra do mestre a sua "força moral" para, somente mais tarde, "encontra-la nos ditames de sua própria consciência" (DURKKHEIM, 1967, p. 56).

Essa criança a quem apenas cabe o hábito de ver a autoridade na voz do educador e reconhecer a sua força moral que é internalizada em sua consciência para adquirir uma liberdade, sinônimo de uma autoridade consentida por outrem, ao qual se submetera na arte pedagógica para se tornar um adulto normal, certamente, suscita uma série de questões. Dentre essas questões, está a do silenciamento a que a infância é submetida para introjetar a voz desse adulto normal, a linguagem de um mundo controlado ou, para usar a expressão de Deleuze (2000), a lógica da sociedade do controle - e não mais a de uma sociedade disciplinar -, na arte pedagógica. Nessas circunstâncias atuais, em que o educador não teria mais fé interior em sua autoridade nem se reconheceria mais em uma missão de causa impessoal, que consiste em inscrever em uma tabula rasa a consciência coletiva, restaria apenas o silêncio a que a infância é submetida para ser sugestionada pela técnica hipnótica, aplicada à arte pedagógica. Por seu intermédio, uma voz de comando de um adulto supostamente normal, o professor, responsável por governá-la por que já governou a si mesmo, sobrepõe-se a esse suposto silêncio da infância, para habitá-lo de uma linguagem e para dar uma determinada voz ao infante: uma linguagem similar ao lógos do adulto e uma voz idêntica a que reverbera na cultura, sem se ocupar de pensar se a sua experiência não teria algo diverso e contrastante com essa linguagem e cultura ou com a possibilidade de mudálas. 
Isso parece ocorrer porque os professores se apoiam, ainda, na criança imaginária e insólita criada por essa tradição pedagógica, que os condenou, como diz Fernandes (1997, p. 67), a "projetar na pedagogia essa criança imaginária fraturada", geradora de uma ameaça angustiante no âmbito da ação pedagógica. É essa ameaça angustiante que faz muitos professores se defenderem contra esse outro ameaçador e dizer que é a infância que está em crise, mantendo intacto o que são para assegurar sua suposta autoridade e parco poder sobre os menores. Raramente percebem que o que está adoecido e o que necessita de tratamento não é a infância, mas o olhar que o adulto lhe lança, proveniente do abandono das virtualidades de sua experiência e do silêncio de suas as potencialidades de narrá-la de um modo diverso do instituído pela linguagem. Penso que, diferentemente do que indicado por Fernandes (1997), não bastaria apenas recuperar essas virtualidades da infância em sua associação com a filosofia para vislumbrarmos novas possibilidades utópicas no presente, pois, se assim o fizéssemos correríamos o risco de recriar romanticamente um ideal paradisíaco de infância, dando continuidade ao proposto por Rousseau.

Não parece ser plausível, também, que os pressupostos de uma educação apoiada na metáfora do crescimento e numa pedagogia que privilegia a infância, como a de John Dewey, poderia ser mais bem sucedida para a consecução desse propósito. Isso porque a defesa de uma educação escolar em que o adulto coordena e a criança aprende por experiência no sentido expresso por Dewey ou, se preferirmos, um dar voz à criança como protagonista da experiência educativa implicaria em alguns problemas, sobretudo, quando se pensa na educação escolar. Se, por um lado, com o filósofo estadosunidense se explicita certa indignidade de falar pelo outro, por essa criança e pelo aluno, dando a eles não apenas a possibilidade de falar por si, como também de aprender a dar voz a própria experiência com a qual aprende e se educa, por outro, essa possibilidade lhe é concedida por

Filosofia e Educação - ISSN 1984-9605 - Volume 4, Número 2

Outubro de 2012 - Março de 2013 
um adulto, pelo educador, em um contexto como o escolar que, premeditadamente, pressupõe um intercâmbio lógico e a necessidade da articulação da fala que, em tese, não encontraria em outrem. Por mais que esse outrem possa aprender a articular o discurso e intercambiar a experiência nesse contexto comunicacional, tudo depende se o educador for hábil para selecionar os problemas, o material e as condições do ambiente escolar para que o pensamento reflexivo ocorra no aluno que, por sua vez, necessita recorrer a uma lógica investigativa se o seu interesse for mobilizado (DEWEY, 1971; PAGNI, 2010a). Tudo depende, portanto, de uma condução da criança e do aluno menos experiente pelo adulto e pelo educador mais experiente e do método pedagógico que esse utiliza para que aquele pense por um método lógico e cognitivo semelhante ao seu. Dessa forma, a arte pedagógica deweyana parece, senão inverter o método utilizado pelo magnetizador, ao menos lançar mão de outro método que deposita sobre a infância a possibilidade de pensar, de falar e de governar a si própria na e pela experiência.

Mesmo que se estabeleça em instituições como a escola, dessa perspectiva, certa proteção para que esse aprendizado do pensar, do falar e do autogoverno ocorram, a arte pedagógica parece se restringir: primeiro, a uma arte que artificializa o modo de aprender da vida, trazendo-o para dentro da escola, nos termos apontados anteriormente nesta tese; segundo, a uma questão de método que consiste em dar sustentação ao aprendizado ético e político colateral, por assim dizer, já que o que se privilegia é o que pode ter consecução e ser avaliado em sua eficiência, isto é, a aquisição de conhecimentos, o desenvolvimento de capacidades e a formação de habilidades e competências; terceiro, a uma questão de governo que, em recusa ao chamado método tradicional e a autoridade do educador, se destina maior possibilidade ao governar da infância e maior espaço ao preparo para que seja protagonista, antes do que coadjuvante, em um 
processo de ensino que pressupõe a aprendizagem. O problema maior, porém, é que a apropriação desta pedagogia assumiu conotações extremas na arte pedagógica acentuando ainda mais essa artificialização da vida, essa metodologização e, sobretudo, essa imagem da infância como protagonista do governo sobre os adultos, ao ponto de Arendt (1993), responsabilizá-la pela crise da educação nos Estados Unidos e pela perda da autoridade no âmbito da educação mundial.

\section{Do governo ao cuidado da infância na arte pedagógica}

Por mais injusta que seja essa crítica que, ao que tudo indica, seria cabível mais ao movimento de educação progressiva nos Estados Unidos do que ao próprio pragmatismo deweyano, ela traz ao centro do debate filosófico educacional contemporâneo tanto um modo próprio de se compreender a autoridade quanto um aspecto político da relação com outrem que permeia a atividade pedagógica que não podem ser desconsiderados a meu ver. Isso porque, de um lado, desloca a questão da autoridade para uma responsabilidade em relação a outrem e a um amor mundi que ultrapassam a relação pedagógica e, de outro, concebe esta última com uma função bastante específica na escola que, enquanto instituição não promova imediatamente a política, desempenha um papel importante na preparação das novas gerações para que atuem politicamente na vida pública, para não dizer que se constitui em uma condição para tal.

No que se refere à autoridade, vale a pena retomar o que Arendt (1993) a caracterizou, como uma responsabilidade por outrem e pelo mundo que remonta a cultura romana e o papel exercido pelos mais velhos sobre o mundo e como guardiães de uma cultura animi. Mais precisamente, além de contar com a experiência singular dos mais velhos, eles exercem sobre a proteção não apenas dos mais novos que nascem para habitar o mundo,

Filosofia e Educação - ISSN 1984-9605 - Volume 4, Número 2

Outubro de 2012 - Março de 2013 
como também deste último, se expondo e se posicionando politicamente em seu favor, mesmo que sua posição possa ser vencida pelos demais e ultrapassada pelos mais jovens. Sob esse aspecto, o que parece nutrir essa autoridade é a phronésis adquirida ao longo da vida, percebida e atribuída por outrem àquele que reconhece a sua importância enquanto sujeito para a vida pública e para o mundo. Algo que somente ocorreria na acepção arendtiana graças à ação no mundo, aos seus modos de relação com outrem e ao seu julgamento reflexivo, capazes de revelar tanto o sentido daquela ação quanto a seu ser no mundo. Nesse sentido, essa noção de autoridade parece se aproximar do que denominarei aqui de um cuidado para com outrem, isto é, de um sentimento de responsabilidade para com os demais participes do mundo e com os destinos do próprio mundo, propondo-se a defendê-lo de sua destruição, dando continuidade a algumas de suas tradições e, politicamente, rompendo com outras que considera ultrapassada para as novas gerações, mas deixando a última palavra a estas últimas na medida em que, gradativamente, adquirem as mesmas condições e possibilidades de julgá-las reflexivamente.

Na medida em que a escola, dessa perspectiva, se responsabiliza por apresentar a criança ao mundo, Arendt (1993) ainda propõe um papel político bem determinado em relação a essa instituição que, como vimos neste capítulo, podem se aproximar em alguns aspectos das análises foucaultianas sobre o tema. Especificamente, em relação à arte pedagógica, a perspectiva aberta pela filósofa política não postula propriamente o governo da infância pelo educador, mesmo criticando o ensino centrado na criança, no aprender fazendo e no jogo, mas busca evitar politicamente que concorra para a atual indiferenciação entre o privado e o público na escola, para a homogeneidade característica da sociedade de massas, como expressão dos modernos totalitarismos. Procura, dessa forma, pressupor um compartilhamento, na relação com o outro, daquilo que é comum e que pode 
ser partilhado no que se refere ao gosto e da tradição que deve ser transmitida para que, efetivamente, a criança entre no mundo, e ao aprender a língua, a cultura e as normas que o regem, possam nele atuar, após adquirirem certa maturidade, politicamente.

Entretanto, como o que é compartilhado, mais do que os significados das tradições e das coisas do mundo traduzidos lógica e cognitivamente ao outro, decorre dos acontecimentos e de certa abertura ao novo promovida pela natalidade (BÁRCENA, 2006), a meu ver torna-se imprescindível à educação escolar preservar um campo de sua interseção com a arte de viver nos termos indicados por Foucault, e não no sentido pejorativo de que as crianças não deveriam ser instruídas e treinadas para as funções básicas da vida designada pela autora. Isso porque, do mesmo modo que Arendt (1993) retoma a cultura romana para defender certo tipo de humanismo, ao retomar a filosofia como modo de vida e como arte do viver no pensamento grego, dos estoicos e dos cínicos, com o pensamento do último Foucault parece ser possível perspectivar uma formação em que a vida se constitui como obra de arte, tal como demonstrado na primeira parte desta tese, que tensiona os modelos formativos nos quais a pedagogia se inspirou e, de certo modo, que a arte de governo pedagógica procurou efetuar.

A arte de viver concebida nesses termos não seria uma simples exposição à vida nua, tampouco um treinamento e uma habilitação para se conseguir a sobrevivência do homem em relação àquilo que se tem de mais básico e corpóreo. Ao contrário, se constituiu em uma ocupação com a própria vida que recebe a denominação de filosofia e que requer um cuidado ético em relação a si mesmo, sendo necessária uma série de exercícios para tal, assim como uma atitude de coragem para enunciar o discurso de verdade que a rege. Nesse sentido, a arte de viver não supõe propriamente uma pedagogia, mas, no caso de se destinar a outrem, ela requer uma psicagogia que, ao se ocupar de uma transmissão de verdade, procura, antes de Filosofia e Educação - ISSN 1984-9605 - Volume 4, Número 2 Outubro de 2012 - Março de 2013 
transformar a esse outrem, a própria transformação e pragmática de si, vendo nesse trabalho de si a possibilidade da criação de processos de subjetivação e novos estilos de existência. Esse cuidado ético de si a meu ver não apenas difere e contrasta com a arte de governo pedagógica, como também a interpela e nela se imiscui na medida em que consiste numa atitude e, parcial ou integralmente, numa decisão do sujeito ético que constantemente transita da esfera da vida para o mundo da escola. Nas ações desses sujeitos não ficam intocadas essa repartição entre o mundo e a vida, realizando advertida ou inadvertidamente um trânsito entre um e outro e constituindo um campo de tensão entre eles que, se percebidos em sua ocorrência, dão-lhes o que pensar mediante os acontecimentos e experiências que aí emergem, transformando a si mesmos e forçando as práticas e os saberes escolares a se modificarem ou a reconhecerem os seus limites. É nesse trânsito que a arte de viver, por mais que faça parte de uma tradição abandonada, pode ser oportuna no presente para se evidenciar a sua imiscuição advertida ou inadvertidamente nos dispositivos disciplinares e normativos da escola, assim como ao tempo massificado e ao controle contemporâneo que a pressionam, resistindo-lhes e, quem sabe, transformando-lhes.

Para que tal efeito ocorresse, no curso formativo da arte pedagógica em que o educador prepara o aluno para o mundo, dispensando-lhe os cuidados necessários, o companheirismo que implica e o amor mundi que pressupõe, parece necessário que se atente para esse campo de tensão gerado pela arte de viver. Isso porque se pode descobrir aí a diferença entre as subjetividades e os modos de subjetivação desses sujeitos éticos, não apenas seus modos de se portarem no mundo, como também, e principalmente, as atitudes (ethos) que assumem diante da vida. Afinal, é essa diferença que interessa ao olhar e ao pensar filosófico educacional, caso se considere que a educação escolar efetivamente auxilia na passagem

Filosofia e Educação - ISSN 1984-9605 - Volume 4, Número 2

Outubro de 2012 - Março de 2013 
dos mais novos da vida privada para a pública, mas que se mantém atenta aos diversos estilos de vida e aos modos de subjetivação que nela perduram.

Tal atenção em relação às diferenças parece importante também para manter uma atitude de respeito às singularidades e à multiplicidade cultural que constitui a sociedade, se desejarmos que a escola apenas seja o começo de uma formação que se prolongue até o fim da vida e também se encontra em outras de suas esferas. E é justamente essa diferença que escapa a uma arte de governo pedagógica ou, mais especificamente, a uma arte técnica que postula tornar igual o nível de conhecimento do aluno ao do educador, pois, ela se relaciona a um ethos a ser construído, antes do que a uma epistême a ser adquirida, que perduram por toda a vida, não se restringindo ao tempo e ao espaço escolar. Por outro lado, o plano político em que o cuidado com o outro, o companheirismo que implica e o amor que pressupõe não se restringem apenas a um sentimento comum necessário para que o educador se responsabilize pelo outro, mas a experiências singulares que se encontram nessa relação e que podem produzir acontecimentos capazes de transformar a esses mesmos sujeitos, sua subjetividade e seus modos de ser, resultando em formas de subjetivação distintas para a condução de suas vidas. Esses encontros com o outro, que escapam à regulamentação, à normalização e ao planejamento das práticas e saberes escolares, constitutivas da arte pedagógica, por se tratar do fortuito, do acaso e da vida - o que advém e provoca o acontecimento -, provocariam nos sujeitos compreendidos nessa relação, que se lhe apresenta como diferente, um se preocupar consigo mesmos, como um ato de pensarse que implica, eticamente, em transformar a si próprio. Nesse sentido, o cuidado com o outro implícito na ação pedagógica de um desses sujeitos, o educador, pressupõe um cuidado ético de si mesmo, similar àquele que pode ser suscitado em outrem, em seus alunos. Dessa forma, essa reinterpretação do cuidado político do outro mediante o cuidado de si confere à ação 
pedagógica um suposto ético no qual se sustenta a sua dimensão política e que adentra a essa arte de governo da infância no sentido de o educador radicalizar tanto a indignidade de falar e de pensar por esse outrem quanto a retórica dignidade de conceder-lhe a palavra e o pensamento sem que estejam preparados e tenham condições de sustentá-los publicamente.

Para tal propósito, parece ser necessário que, nessa arte de governo, enquanto sujeito ético, o educador se ocupe em sua relação pedagógica com outrem de sua dívida para com a infância, com a infância de seu próprio pensar e com o seu testemunho, nos termos abordados pelo projeto filosófico lyotardiano (PAGNI, 2006a, 2006b). Isso não significaria tratar de sua infantilidade como suposto pela psiquiatria (como analisou Foucault), nem de sua imaturidade sexual ou emotiva (como sugerido por Adorno), embora pudessem também fazer parte desse cuidado, mas ocupar-se daquelas experiências que, nas relações pedagógicas com a infância outrem, o remetem a um outro de si que não consegue articular em palavras ou, para usar uma expressão de Agamben (2005b), a um experimentum linguae.

É justamente o acontecimento gerado desse encontro com a própria infância que produz um pensar a partir de outrem num outro de si e se transformar numa arte de governo que espera desse si dar a forma e conduzir, enquanto também está sujeito a ser formado e conduzido, produzindo outros modos de subjetivação e estilos de existência, mesmo em um tempo e um espaço que os interditam como os da escola. É nessa relação com a do acontecimento da infância, do pensar e da transformação de si, suscitada na arte pedagógica, que pode fazer com que, na procura de governá-la, o educador vislumbre a possibilidade senão de uma alteridade em relação a outrem, ao menos uma familiaridade estranha que lhe permita acercar-se de seus alunos. O educador poderia se aproximar das diferenças suscitadas na relação com outrem, com os seus processos de subjetivação e experiências singulares, não para tornar idênticas as suas, tampouco para

Filosofia e Educação - ISSN 1984-9605 - Volume 4, Número 2

Outubro de 2012 - Março de 2013 
que as suas se tornassem iguais as de seus alunos, mas para mantê-las, abertamente, como um modo de continuar em devir enquanto sujeito e fazer de sua vida uma obra de arte. Dessa forma, a arte de governo pedagógica poder ser confrontada com um cuidado político do outro que, pressupondo essa transformação de si do educador, poderia auxiliar no cuidado de si de outrem, oferecendo as condições para que tal transformação também fosse buscada pelos alunos, ao menos por aqueles dispostos e com coragem para fazerem de sua vida uma obra de arte, ainda que essa possibilidade seja proscrita pelo mundo e pela biopolítica atual.

\section{Considerações finais}

Nas circunstâncias históricas atuais parece difícil combater tanto as formas de pleno domínio sobre a infância quando a de seu governo absoluto na arte pedagógica recobrando as virtualidades de seu cuidado nos termos postulados, em sua gênese moderna, por Kant e, principalmente, por Rousseau. Embora uma boa parte dos discursos pedagógicos em circulação se funde nos metadiscursos de suas filosofias da educação, parecem não apenas contradizer as atuais formas de governo exercidas na arte pedagógica, como também ser insuficiente para restituir nesta arte o cuidado com a infância que aquelas filosofias pressupunham, como anteriormente demonstrado, nos limiares da modernidade. Isso porque pressupõem o acento em certas formas de governo do outro, no caso de Kant, e de governo de si, no caso de Rousseau, que possuem uma razão de ser e um sentido estratégico historicamente, esquecidos pelos discursos pedagógicos atuais, que os apropriam inadvertidamente em sua literalidade. Supõem a partir dessas formas de governo, ainda, as suas respectivas noções de cuidado, porém, para ambos esta é concebida como uma necessidade natural para que o adulto ofereça as condições de possibilidade à criança para que se

Filosofia e Educação - ISSN 1984-9605 - Volume 4, Número 2

Outubro de 2012 - Março de 2013 
desenvolva e se forme livremente, em conformidade à sua própria natureza, no caso de Rousseau, e a uma ideia transcendental de sujeito, no caso de Kant, algo que também continua a ser almejado habitualmente pelos discursos pedagógicos para defenderem certa ideia de liberdade e de emancipação do aluno.

O problema é que as condições dessa sua enunciação ou, mesmo, do sujeito que enuncia tal discurso, o educador, raramente são pensadas no presente e, quando o são, assumem um caráter fundacionista que não raro consideram natural e necessário o cuidar de outrem, do aluno, para moldá-lo ou para deixar moldar-se por si mesmo. E, desse modo, o cuidado se converte em governo, com os riscos salientados anteriormente de se tornar um governo pleno ou domínio sobre a ou da infância. Este é o diagnóstico que pode se depreender deste artigo, ao abordar o desenvolvimento das relações entre a arte pedagógica e a infância.

Diante tal diagnóstico, retomar o pensamento desses filósofos modernos, especialmente, o de Rousseau, seria oportuno na medida em que gerasse certo estranhamento ao próprio educador que os desconhecem e, quem sabe, um dobrar-se sobre o governo que ele próprio exerce na arte pedagógica, em vistas a pensar em ocupar-se de si e de se subjetivar em suas práticas. Dessa forma, a meu ver poderia se vislumbrar certa atualidade na leitura do Emílio de Rousseau, almejada não em razão do conhecimento de seu conteúdo e de sua eventual utilidade pedagógica, mas, principalmente, do efeito que produz sobre o seu leitor, o educador, no sentido de instiga-lo a transfigurar-se e buscar na sua arte de governo pedagógica formas de cuidado com a infância que poderiam resistir ao seu pleno domínio. Contudo, a potencialidade da obra de Rousseau ou de qualquer outro filósofo moderno para tal a produção desse efeito não me parece suficiente para produzir tal efeito, sobretudo, quando a sua leitura não vislumbra outra tradição filosófico-educacional da abordagem do problema da relação da 
arte pedagógica com a infância, por um lado, e o seu leitor não tiver essa disposição para ocupar-se de si, transfigurar-se e livrar-se do que o aprisionam, como educador, as formas de governo pleno sobre a e da infância em suas práticas, por outro. Nesses casos, alguns estudos no campo filosófico educacional vêm oportunizando outra leitura dos filósofos modernos e, especialmente, de Rousseau ao associá-lo à tradição que provêm da preponderância do cuidado ético de si mesmo, como ocorre no recente trabalho de Dalbosco (2011), ao relacionar a concepção rousseauniana de natureza com o estoicismo. Outros, como pretendido aqui, procuram complementar que, independente da leitura que dele se faça, tudo depende da abertura do leitor, do sujeito e, particularmente, do educador a mobilizar sua aptidão e coragem para a assunção de uma atitude ética de ocupar-se de si para que, então, resista aos riscos eminentes das formas de governo pleno sobre a ou da infância, que se cristalizaram em suas práticas.

$\mathrm{Na}$ arte de governo pedagógica, assim, o educador pode aprender a cuidar da infância, se abrindo a ela e à diferenciação que provoca, em vistas a ocupar-se consigo, transformar-se e transformar as relações existentes. Isso porque somente essa experimentação faria jus à tradição que a compreende como constitutiva da arte de viver e seria digna em responder aos desafios interposto pelo presente a essa atividade filosófica educativa. Tanto na leitura de sua obra quanto na interpelação que provoca ao seu leitor, o pensamento de Rousseau permaneceria, nesses termos, vivo e potente para evidenciar o cuidado com a infância na arte de governo pedagógica como um dos desafios primordiais no presente, não apenas podendo, como também devendo ser retomado. 


\section{Referências}

AGAMBEN, Giorgio. Infância e História: destruição da experiência e origem da história. Belo Horizonte: Editora UFMG/Humanitas, 2005b.

ARENDT, H. Entre o passado e o futuro. 3. Ed. São Paulo: Perspectiva, 1993.

DALBOSCO, C.A. Educação Natural em Rousseau: das necessidades da criança e dos cuidados do adulto. São Paulo: Cortez Editora, 2011.

DELEUZE, G. Conversaçoes. 3.ed. Rio de Janeiro: Editora 34, 2000.

DEWEY, John. Experiência e Educação. São Paulo: Cia. Editora Nacional, 1971.

DURKHEIM, E. Educação e sociologia. 7.ed. São Paulo: Melhoramentos, 1967.

FERNANDES, H. Infância e modernidade: doença do olhar. In:

FOUCAULT, M. Soberania e disciplina. In: Microfísica do Poder. 9. Ed. Rio de Janeiro: Graal, 1990, p. 179-192.

. Vigiar e Punir. 8. Ed. Petrópolis: Vozes, 1991.

. O que é crítica? (Crítica e Aufklärung). Cadernos da FFC (Marilia):

Foucault - História e os destinos do pensamento. 9(1), 169-189, 2000.

. Hermenêutica do Sujeito. São Paulo: Martins Fontes, 2004.

. Tecnologías del yo: y otros textos afines. Barcelona: Paidós, 2008.

GHIRALDELLI JÚNIOR, P. Infância, escola e modernidade. São Paulo: Cortez/UFPr, 1997, p. 61-82.

KANT, I. Resposta à pergunta: o que é o esclarecimento (Aufklärung)? In: . Textos seletos. Petrópolis: Vozes, 1974, p. 100-117. . Ideia de uma história universal de um ponto de vista Cosmopolita. São Paulo: Brasiliense, 1987. . Sobre a Pedagogia. Piracicaba: Editora Unimep, 1995.

PAGNI, P. A. Infância (verbete) In: CARVALHO, A.D. (coord.) Dicionário de Filosofia da Educação. Porto: Editora Afrontamentos, 2006a.

PAGNI, P. A. Infância, experiência formativa e filosofia. In: TREVIZAN, A.L.; TOMAZETTI, E.M. Cultura e Alteridade: confluências. Unijuí: Editora Unijuí, 2006b, p. 39-60.

Filosofia e Educação - ISSN 1984-9605 - Volume 4, Número 2

Outubro de 2012 - Março de 2013 
Da polêmica sobre a pós-modernidade aos 'desafios' lyotardianos à filosofia da educação. Educação e Pesquisa, São Paulo: FE-USP, v.32, p.567 588, set./dez.2006c.

. Escola, Estética e ética. Educaşão [história da pedagogia: John Dewey]. São Paulo: Editora segmento, v.6, p.32 - 43, dez./2010a.

- Infância, Arte de Governo Pedagógica e Cuidado de Si. Educação \&

Realidade. Porto Alegre, v.35, n.3, p. 99-123, set/dez.2010b.

ROUSSEAU, J-J. Emílio ou Da Educação. São Paulo: Martins Fontes, 1995. 